\title{
PECULIAR PERQUISITES AND PERNICIOUS PRACTICES
}

\author{
EMBEZZLEMENT IN THE WEST OF \\ ENGLAND WOOLLEN INDUSTRY, c. 1750-1840*
}

\begin{abstract}
SUMMARY: This paper examines the character and significance of embezzlement in the woollen industry of the West of England in the years from $c$. 1750 to 1840 in the light of the recent debate which sees the period as witnessing major developments in the eradication of perquisites and in the formulation of the wage. It examines the dimensions of embezzlement, its correlation with economic fluctuations and its importance for the economy of both the clothier and the embezzling worker. It shows that tighter legislative sanctions failed to check the illicit trade in embezzled wool, which by the early nineteenth century constituted a well-organised black market, and it considers the effect of this trade in "slinge" upon economic and social relations in the industry.
\end{abstract}

Embezzlement was rife in the manufacturing industries of eighteenth- and early nineteenth-century England. Purloining by the labour force of the raw materials entrusted to it for processing was endemic in a host of trades in all regions, each being graced by its own nomenclature. Thus:

Bugging to the hatter, cabbage to the tailor, blue pigeon flying to plumbers and glaziers, chippings to shipwrights, sweepings to porters, red sailyard docking to navy yard workers, fents and thrums to weavers, vails to servants, privileges to west country clothiers, bontages to Scottish agricultural labourers, scappings and waxers to coopers, wastages to framework knitters, in all these the eighteenth-century labourer appropriated a part of his product or a part of the materials of his labour. ${ }^{1}$

Such appropriation was not necessarily seen by the appropriators as an illicit activity. What an employer saw as embezzlement was frequently regarded as a perquisite of the trade by the workman, as a legitimate additional benefit, sanctified by custom and occasionally by law, which augmented more formal remuneration. Thus the line between embezzle-

* I am grateful to Dr. L. D. Schwarz for his helpful comments on an earlier draft of this paper.

${ }^{1}$ P. Linebaugh, Summary of paper, Bulletin of the Society for the Study of Labour History, 25 (1972), p. 13. 
ment and perquisites was rarely a clear one. Like custom it was liable to redefinition and reinterpretation according to context.

Recent studies, in particular those by Linebaugh, Rule and Styles, ${ }^{2}$ have presented interesting overviews of this ubiquitous phenomenon. Debate has centred in particular upon the significance of embezzlement and perquisites within the changing industrial and social relations of the early Industrial Revolution and upon the evolving nature of the wage. Linebaugh has argued that this period witnessed increasing pressure from capital to eradicate perquisites in an attempt to undermine custom and to redefine labour-capital relations. Rule's work reflects this view in part but places embezzlement and perquisites more firmly within a "field of force" by which labour counterbalanced such oppressions of capital as truck, arbitrary deductions or false weights and measures. Styles has been more concerned to address the role of perquisites within the context of legal and economic relationships, questioning Linebaugh's thesis that the later years of the eighteenth century witnessed the deliberate criminalisation of such customary practices that significantly curbed non-monetary forms of remuneration. Each author, however, has recognised the need to examine the history of embezzlement and perquisites within "the setting of particular industries and particular industrial regions" in order "to specify the precise character and extent of change in context". ${ }^{3}$ This article attempts to do this for one particular industry and region: the wool textile industry in the counties of Gloucestershire, Wiltshire and Somerset, an industry always referred to as the West of England woollen industry.

The West of England woollen industry of the mid-eighteenth century represented the apogee of the putting out system, that most characteristic form of organisation of pre-industrial manufacture. The industry was controlled and dominated by wealthy merchant capitalists, the famous gentlemen clothiers. Tucker noted in 1757 :

One Person with a great Stock and large Credit, buys the Wool, pays for the Spinning, Weaving, Milling, Dying, Shearing, Dressing, etc., That is, he is the Master of the whole Manufacture from first to last and perhaps imploys a

${ }^{2}$ Linebaugh, Bulletin of Labour History, pp. 11-15; J. Rule, The Experience of Labour in Eighteenth-Century Industry (New York, 1981), pp. 124-146, and J. Styles, "Embezzlement, industry and the law in England, 1500-1800", in M. Berg, P. Hudson and M. Sonenscher (eds), Manufacture in Town and Country Before the Factory (Cambridge, 1983), pp. 173-210. See also C. Emsley, Crime and Society in England, 1750-1900 (London, 1987), ch. 5, for a useful overview. See also abstracts of papers at a conference held at Birmingham University in 1986, chaired by Dr. L. D. Schwarz, published in Bulletin of the Society for the Study of Labour History, 52 (1987), pp. 33-45.

${ }^{3}$ Styles, "Embezzlement", p. 205. 
thousand Persons under him. This is the Clothier whom all the rest are to look upon as their Paymaster. ${ }^{4}$

Not all gentlemen clothiers were "worth from $£ 10,000$ to $£ 40,000$ a man", but the clothier's role remained the same, whether he was a great Paymaster or a struggling manufacturer on the verge of insolvency. Of the four main manufacturing processes - preparation, spinning, weaving and finishing - the clothier controlled only the first. While wool sorting often involved the clothier himself and scribbling was generally undertaken by scribblers working in the clothier's shops, spinning and weaving, the two most populous trades, were performed by independent journeymen and their families working in their own homes, while fulling, dyeing and cloth finishing were carried out on commission in the shops of independent master workers. While the materials returned briefly to the clothier's care after each stage of manufacture when the worker received his remuneration on a piece work basis, the West of England clothier had little control over the pace or quality of work while in execution after first putting it out to be spun.

This structure of production, a classic example of the proto-industrialisation thesis' Verlagsystem, had many advantages for the capitalist. Whereas in the West Riding Kaufsystem ${ }^{6}$ the first three manufacturing processes were all undertaken by the master clothiers, their families and live-in journeymen, the craft specialisation of the West of England labour force ensured that at each stage of production specialist skills were available to maximise quality. This reservoir of skill, together with the capital of the clothiers who were able not only to buy the finest wools but could also afford to hold large stocks and to sort wool into between seven and twelve different qualities - the master clothiers of Yorkshire rarely sorted into more than two or three qualities - meant that West of England woollen cloth was the finest available. Although expensive, in its feel, durability and retention of colour West of England cloth was unrivalled in quality until Benjamin Gott of Leeds devoted his considerable energies to matching it at the turn of the eighteenth century. ${ }^{\text {? }}$

4 J. Tucker, Instructions for Travellers (1757), pp. 24-25.

${ }^{5}$ D. Defoe, A Tour through England and Wales (1724-1726; Everyman edn. 1928), Vol. I, p. 281.

${ }^{6}$ For an excellent introduction to this debate see Berg, Hudson and Sonencher, Manufacture in Town and Country, ch. 1. For discussion of the consequences of the different industrial structures of the West of England and the West Riding for their economic development and the relevance of proto-industrialisation theory, see A. J. Randall, "Work, culture and resistance to machinery in the West of England woollen industry" in P. Hudson (ed.), Regions and Industries: A Perspective on the Industrial Revolution in Britain (Cambridge, 1989), pp. 175-198.

${ }^{7}$ W. B. Crump, The Leeds Woollen Industry, 1780-1820 (Thoresby Society, Leeds, 
While this division of labour, far more complex than Adam Smith's famous model of the pin factory, offered undoubted benefits, it was not without its drawbacks. Specialisation created a strong sense of craft and trade consciousness which was manifested in a vigorous and assertive defence of custom and of living standards by all West of England labour groups. Industrial relations in the eighteenth century were frequently acrimonious and conflicts by no means always resolved in favour of capital. Likewise, while the outworking structure of the industry meant that capital risks were spread wide - it was the workers and master craftsmen whose tools and plant stood idle during depressions, not the clothiers - in times of prosperity it meant that clothiers had no means of increasing rates of production to meet urgent orders. While St. Monday was a badge of status to the "independent" woollen workers, it was an unending source of irritation and frustration to their direct and indirect employers, the clothiers. According to the clothiers, however, even St. Monday was less of a problem than embezzlement. Clearly, since valuable materials were for so long out of their ken, the opportunities to purloin it were legion. Clothiers frequently complained that these opportunities were not neglected by their workforce and asserted that the trade in "slinge", as embezzled wool was known in the West of England, constituted a major threat to their economy.

In the West of England, as elsewhere, the line between embezzlement and perquisite was a fine one. The woollen workers certainly had no legal rights to retain any of the wool on which they worked and clothiers since the reign of James I had endeavoured to obtain legislation to prosecute all forms of embezzlement. Custom, however, dictated that clothiers generally accepted the weavers' retention of thrums, those ends of warp thread left on the loom after the finished piece was taken off. Thus, W. A. Miles, the Handloom Weavers' Commissioner for Gloucestershire, reported in 1838 that 'Many of the old weavers look upon the embezzlement of a 'vew ends' as their peculiar perquisite; so common was the practice." ${ }^{\prime 8}$ Indeed, a Gloucestershire clothier giving evidence in 1803 admitted that weavers were commonly allowed to retain thrums even though these undoubtedly belonged to the clothiers. ${ }^{9}$ Equally, clothiers rarely quibbled about flock, small lengths of woolfibre left over after spinning or scribbling, and there is no indication that the fluff and discarded pile from cloth dressing was ever returned with a finished cloth. Clothiers, however, certainly recognised no right or custom to retain carded wool, spun yarn or weft and they remained

1931), pp. $48-56$.

${ }^{8}$ B.P.P., 1840, Vol. 24, Reports from the Assistant Handloom Weavers' Commissioners, Part V (Gloucestershire), p. 473.

${ }^{9}$ B.P.P., 1802/3, Vol. 7, Minutes of Evidence taken before the Select Committee on the Woollen Clothiers' Petition, p. 320. 
convinced that their "losses" were well in excess of anything customarily acceptable.

Attempting to get to grips with the dimensions of embezzlement raises major and well-recognised problems for the historian, as indeed it did for the clothiers of the West of England. Summary convictions for first-offence embezzlers frequently took place before petty sessions, of which scant records have survived. Cases for receiving offences and prosecutions of notorious embezzlers were generally dealt with at quarter sessions or sometimes, if the crime seemed of larger-than-usual magnitude or if an example needed setting, at the assizes. These are better documented, but, as with all discussions of eighteenth- and early nineteenth-century crime, are indicative more of levels of policing and of willingness to prosecute than of the level of crime itself. In a system of justice which depended upon private prosecution, cases brought over embezzlement reflect on the motivations of the victim as much as on the nature or the incidence of the offence. A supplementary source of value may be found in the newspapers. Certainly at times the newspapers in the West of England saw their role as being to publicise prosecutions of embezzlers and receivers in order to deter others. Their coverage of such cases and the publicity given to associations to prosecute such offences, however, was variable. The Gloucester Journal, conscious of its important readership in the woollen manufacturing districts, was more assiduous in reflecting their interests than were the Bath or Salisbury papers of the views of the clothiers of Wiltshire and Somerset. The ensuing impression that Gloucestershire experienced a greater problem of embezzlement may not therefore accord to the eighteenth-and early nineteenth-century reality. Nonetheless, this evidence, taken together with the evidence of interested parties to Parliamentary select committees, to commissioners and to the press and wider public, constitutes all that is available and must be utilised, though with caution.

How easy was it to embezzle wool at the various stages of manufacture? Evidence presented to a Parliamentary Select Committee by some Gloucestershire clothiers in 1774 provides us with one view. This Committee was established in response to a petition presented by clothiers of Wiltshire, Somerset and Gloucestershire in that year, complaining "that many new Species of Frauds and Embezzlements have been discovered and practised by the Manufacturers of every Denomination", thereby causing them "heavy loss". ${ }^{10}$ It is clear that clothiers in the West of England had been increasingly angered by such losses since 1766 and their pressure on the courts had produced a series of swingeing and exemplary sentences. Thus in 1768 John Robbins of Calne in Wiltshire was sentenced to death for stealing yarn and Solomon Legg of North Nibley in Gloucestershire received seven

10 Journal of the House of Commons, Vol. 34 (1772-1774), p. 414. 
years' transportation for stealing 9lb of scoured wool, the property of Samuel Adey of Dursley. William Pritchard received six months for stealing 10lb of yarn in 1771 and Jeremiah and Thomas Workman were sentenced to two years' imprisonment and ordered to be burned in the hand for stealing and receiving yarn. The press responded by highlighting the trials. Thus the Gloucester Journal described the trial of a Rodborough weaver, Stephen Mills, as being "of the utmost importance to the woollen trade" when he was charged with buying and receiving thrums. Mills received a six month sentence. ${ }^{11}$ These years were certainly difficult ones for the industry. Poor trade put pressure upon profit margins and living standards alike. Petitions in March 1774 from clothiers of Westbury, Warminster and Heytesbury and those from many Gloucestershire clothiers protesting against measures to promote the Irish linen trade, lamented that their industry "is already greatly on the Decline to the injury of your Petitioners and the distress of great numbers of poor Manufacturers who are out of Employ". ${ }^{12}$ Similar pressures in Yorkshire and Lancashire culminated three years later in their demands for more stringent law enforcement over embezzlement which gave rise to the Worsted Acts establishing the Worsted Committee. ${ }^{13}$

Several prominent Gloucestershire clothiers gave evidence to the 1774 Parliamentary Committee and their statements provide useful information about methods of embezzlement. Thomas Pettat listed the ways in which the different trades were able to purloin a part of their raw materials. Pickers, he claimed, could embezzle one pound in twenty without possibility of detection by throwing the wool onto wet stones "whereby it impregnates the water and they bring it home full weight". Scribblers could steal one pound of wool by substituting it for the addition of a like weight of oil which, he believed, they could sell for up to $3 \mathrm{~s}$. $5 \mathrm{~d}$. per $1 \mathrm{~b}$, the loss to the clothiers being $4 \mathrm{~s}$. per $\mathrm{lb}$, the value of scribbled Spanish wool. Spinners could increase the weight of their yarn by suspending it over a boiling pot so that it absorbed steam. They could thereby embezzle half a pound in six. ${ }^{14}$ Weavers, Pettat asserted, were able, by beating the weft up loosely, to hold back 5 or $6 \mathrm{lb}$ of yarn in a piece of 30 ells weighing some $60 \mathrm{lbs}$, which, if Spanish wool, was worth from $4 \mathrm{~s}$. $6 \mathrm{~d}$. to $5 \mathrm{~s}$. a pound. Thomas Cooper, a Minchinhampton clothier, and Thomas Tippets of Dursley disagreed with this, believing that the weaver could only steal 3 or $4 \mathrm{lb}$ per piece, a substantial proportion nevertheless. "Which frauds", Pettat claimed, "cannot be discovered as the cloths are always brought home wet." Tippets,

${ }^{11}$ Gloucester Journal, 18 January and 10 October 1768; 21 January, 18 March, and 29 July 1771.

${ }^{12}$ Commons Journal, Vol. 34, p. 574.

13 Commons Journal, Vol. 36 (1776-1778), pp. 85, 113.

14 A similar accusation was made in 1784 . "The poor spoil our yarn by dirtyness, bad spinning, damping and other frauds". Gloucester Journal, 9 February 1784. 
Cooper and Pettat all had examples of their own workmen embezzling wool. One of Pettat's weavers

had woven eight or ten pieces of cloth before any of them came to the scale to be weighed, when it appeared they were 7 or $81 \mathrm{~b}$ a piece too light; upon which discovery [Pettat] examined his books to see what the weaver was then at work upon and found he had two blues; which when he brought home, he certified he had put the whole of the yarn entrusted to him into the two cloths; but upon searching his house, [Pettat] found 13lb of blue yarn which he should not have suspected if the former cloths had not come home lighter than they ought to have been; whereupon the weaver was committed to prison for fourteen days as the law directs. ${ }^{15}$

Historians such as Styles have taken these claims broadly at face value and made various calculations from them. ${ }^{16}$ But how far are they to be trusted? Certainly if Pettat were correct, embezzlement existed on an astonishing scale. If pickers and scribblers were stealing $1 \mathrm{lb}$ in 20 and spinners and weavers $1 \mathrm{lb}$ in 12 as Pettat asserted, the result would have been a total loss in excess of $16 \mathrm{lb}$ of wool for every cloth of $60 \mathrm{lb}$ weight which was taken to the fulling mill, or some $25 \%$ over and above the finished cloth's wool content. Simply costed in terms of the value of the raw wool this might amount to a loss of at least 48s. in 1774. However, the clothier was, of course, paying for artisans to improve the value of the wool which their successors then purloined. Thus the pickers would steal wool only at its raw value of say $3 \mathrm{~s}$. per $\mathrm{lb}$, but the scribbler and spinner stole picked wool and the weaver stole spun wool worth around 4s. and 4s. $6 \mathrm{~d}$. respectively. In total, according to Pettat's figures, their embezzlements would cost the clothier some $63 \mathrm{~s}$. $6 \mathrm{~d}$. Since the cloth might finally sell for around $£ 35$ this loss might amount to some $9 \%$ of its value. ${ }^{17}$ These are extraordinary figures which require careful consideration.

Clearly if Pettat's claims were true, the clothiers not only suffered "heavy loss" but were guilty of appallingly sloppy quality control. The pickers and scribblers, after all, usually worked directly for the clothiers in their own workshops and under their direct supervision. Spinners had their wool weighed out for them when their work was put out. And they were paid on a piece-work basis according to the weight as well as to the length and fineness of the yarn they returned. Weavers likewise had their yarn and warp threads measured out for them and, though not usually weighed, we may assume that a clothier, having paid a rate per pound for warp and weft

15 Commons Journal, Vol. 34, pp. 451-452.

${ }^{16}$ Styles, "Embezzlement", pp. 207-208.

${ }^{17}$ For costs of wool and cloth see J. de L. Mann, The Cloth Industry in the West of England from 1640-1880 (Oxford, 1971), ch. IX and Appendix III. 
to the spinners, would have a clear idea of the finished weight as well as the finished dimensions of the cloth they expected back. The Select Committee, no doubt surprised by his figures, asked Pettat "whether there are no methods by which he might discover the frauds by weighing the manufacture some time after he had received it, and comparing the weight at that time with the weight at the time of delivery?" Pettat replied that "in respect of wool and yarn, it may be done by putting it in a room where there is a fire [. . .] but it would be very inconvenient upon account of the room and time it would take up" ${ }^{18}$ This apparently lazy attitude towards making any effort to resist embezzlement ill-accords with the petitioners' claims concerning the urgent need for legislative intervention.

An alternative view on the ease of embezzlement was given to the Select Committee investigating the woollen industry in 1803 by John Niblett, a weaver from Stroud, and Thomas Richmond, a Trowbridge master weaver who had also been a clothier. Niblett admitted that a great deal of embezzlement took place in Gloucestershire but his evidence indicates that the scale was considerably less than Pettat had claimed in 1774 . Niblett was in a particularly good position to judge, having worked both as an out-weaver and as a "wool-oft man", that is, giving out and receiving back wool and cloth for his employer. A favourite method of the embezzling weaver, Niblett claimed, was to fill up the ground of the woven cloth with whiting or chalk, thereby giving it both bulk and substance to replace the missing yarn. However, Niblett stressed, such fraud was easily discovered by putting some of the cloth in a basin of water before scouring and checking the water's colour. Cloths could be kept up to the required length by an unscrupulous weaver beating up the weft rather more loosely than was normal. This again, however, could be detected by an experienced man passing the cloth over a perch to look for weaknesses. Cloths were anyway generally perched upon being brought home so that the clothier or his wool-oft man could check for flaws or faults in tl e weave prior to paying the weaver. Richmond echoed these views. Both men stressed that if a clothier had any suspicion of a cloth being under-weight, they would immediately send it to be scoured and then weighed. Thus, as the chain and abb had been carefully measured out, skein by skein, to the weaver when he received his work, the woven weight after scouring should correspond with the original. Niblett claimed, as an experienced man, to be able to judge a piece of thirty or thirty-four ells, containing some 60 to $65 \mathrm{lb}$ of wool, to within one pound. ${ }^{19}$ Anyone with experience of craft industries will recognise that this was no idle boast. The feel, weight and weave of a cloth could not easily be disguised by wetting or by filling the ground with alien matter. Clothiers

${ }^{18}$ Commons Journal, Vol. 34, pp. 451-452.

19 B.P.P., 1802/3, Vol. 7, pp. 28-32, 98. 
were taught from childhood to learn the feel of their raw material and their role meant that they could, if they chose, be constantly inspecting their raw materials at the point of payment to reinforce that training. In 1839 both Austin and Miles, Commissioners for Wiltshire and Gloucestershire respectively for the Handloom Weavers' enquiry, agreed, "every manufacturer who pays due attention will detect embezzlement with the moral certainty of being right though unable to bring legal proof'. ${ }^{20}$

Embezzlement on the scale claimed by Pettat and his colleagues in $\mathbf{1 7 7 4}$ can only be explained by spectacular complacency, which is unlikely, or as deliberate hyperbole. It is probably the case that standards of inspection in the mid-eighteenth century were not as careful as those found at the end of the century when pressure on profit margins was keener. However, it would be difficult to imagine them being quite so slipshod in view of the value of the raw material. Clothiers in 1803 too complained of embezzlement perpetrated by all their workers, though weavers were particularly blamed. By this date machinery had displaced both the scribblers and the domestic spinners (though, as I shall note below, mechanisation did not preclude embezzlement) leaving weaving as the only out-working trade. However, while all lamented their losses, their claims were much reduced from those made in 1774. John Jones, a prominent Wiltshire gentleman clothier, factory owner, innovator and magistrate, asserted that his losses due to embezzlement were heavy. They amounted, he stated, to ten shillings on every cloth he made. While this would have been no small loss on a cloth by then costing around $£ 25$ - the result of increased mechanisation - this would have represented only 2 or 2.5lb of Spanish wool throughout all stages of production or $2 \%$ of the finished cloth's value. ${ }^{21}$ This would confirm Niblett's evidence and suggest that, while by no means a negligible cost to the clothiers, embezzlement would be undetectable only if it remained low scale. It would show up in losses in stock books when auditing rather than at the point of payment for services. Workers who exceeded these narrow margins relied upon their employer's inattention to his job to avoid discovery and prosecution.

Not all losses of wool could be attributed to deliberate embezzlement. Austin noted in 1838: "The manufacturer gives out a certain quantity of shoot [weft] which he thinks requisite to make a firm cloth; the weaver would not or could not put so much shoot into the cloth; he did not dare bring it back and possibly sold it." 22 Austin's report was echoed by H. S. Chapman in the West Riding in 1838 when he noted a case of a weaver who,

20 B.P.P., 1840, Vol. 23, Report from the Assistant Handloom Weavers' Commissioners, Part II (Southwest of England), p. 466; B.P.P., 1840, Vol. 24, pp. 473-475.

${ }^{21}$ B.P.P., 1802/3, Vol. 5, Report from the Select Committee on the Woollen Clothiers' Petition, pp. 14-16; B.P.P., 1802/3, Vol. 7, pp. 334, 338; Mann, Cloth Industry, p. 321.

22 B.P.P., 1840, Vol. 23, p. 466. 
unable to work all the yarn into the cloth, had put the rest of the weft in the clothier's garden because "his sense of right and wrong would not allow him to keep it". ${ }^{23}$ Clothiers were less easily persuaded of such scruples in their workforce. However, legitimate losses did occur in the process of production. As noted, flock and thrums were viewed as waste and their loss over time must have constituted a not inconsiderable sum.

Although the clothiers in 1774 were successful in their bid to tighten up the law and stiffen penalties for embezzlement, ${ }^{24}$ there is little evidence that the new Act significantly reduced the incidence of the crime. And while the claims of losses due to embezzlement made in 1803 and after were not as inflated as those made in 1774 , there is no sign that the problem grew any less vexing. Edward Sheppard for example claimed in 1803 "embezzlement takes place to an enormous extent in the houses of the weavers", while Jones reported that, as a magistrate, he came across numerous complaints of embezzlement. ${ }^{25}$ And in 1838 the Handloom Weavers' commissioners reported that embezzlement remained common. Thus the Wotton constable, Charles Cogswell, told Miles that "It is his opinion that slingeing is still carried on to the same extent as ever." 26 Nevertheless, it is clear that embezzlement was perceived to be a greater problem in some periods than in others. Why was this the case?

Periods of poor trade certainly sharpened conflict between clothiers and woollen workers and provoked sustained complaints about embezzlement. Historians have often assumed that these complaints reflected increasing levels of actual embezzlement as workers sought to supplement falling living standards by purloining more materials. This view was supported by Austin in 1839. "When a valuable material is placed in the care of a man at times devoid of food [. . . ] it requires a great deal of honesty not to steal a part." 27 This is certainly a plausible argument since the temptation to embezzle wool must have been greater when the fear of want grew most acute. However, in times of depression less work was put out and throughput in the clothiers' workshops was much reduced, thereby allowing clothiers more time to check for frauds. And since their own standards of living

${ }^{23}$ B.P.P., 1841, Vol. 10, Report of the Commissioners inquiring into the Condition of the Unemployed Handloom Weavers, pp. 89-90. See also B.P.P., 1840, Vol. 23, Part III (West Riding of Yorkshire), pp. 546-547.

${ }_{24} 14$ Geo III, c. 25, An Act for the more effectual preventing of Frauds and Embezzlement by Persons in the Woollen Manufactory.

${ }_{25}$ B.P.P., 1802/3, Vol. 5, pp. 15, 16.

26 B.P.P., 1840, Vol. 24, p. 474.

${ }^{27}$ For example J. Tann, Gloucestershire Woollen Mills (Newton Abbot, 1967), p. 56; J. Rule, The Labouring Classes in Early Industrial England, 1780-1850 (London, 1986), pp. 116-117 hints at this, and B.P.P., 1840, Vol. 23, p. 466. For the problem of living standards in the eighteenth century, see L. D. Schwarz, "The standard of living in the long run: London, 1700-1860”, Economic History Review, XXXVIII (1985), pp. 24-41. 
would likewise have been under pressure in depressions, it is probable that they were more conscious of quality controls at such times. It was perhaps this closer attention to monitoring which made the clothiers more conscious of their losses in such periods even if the relative level of embezzlement remained unchanged. Certainly spinners or weavers who increased their misappropriations at such times would have been aware that they ran greater risks of detection than in more prosperous periods. Clothiers could pick and choose from their workforce when work was short and those suspected of embezzlement would not be among the fortunate ones receiving wool. Austin emphasised this point in 1838 when, with work short and weavers super-abundant, clothiers simply dismissed suspect weavers, which "is tantamount to sending him to the workhouse". ${ }^{28}$ Depressions therefore probably made successful embezzlement a great.deal more difficult. Equally, however, a weaver who had regularly been purloining a pound of wool from each $60 \mathrm{lb}$ chain he worked could hardly stop his accustomed practice no matter what the state of the market since his employer, with more incentive to check his work, would be more likely to notice the new fullness of the cloth. Embezzlers who intended to remain undetected had to be content with small and regular exactions. Sudden increases or decreases prompted by fluctuations in the cost of living would have simply invited unwanted scrutiny.

The evidence of prosecutions certainly suggest that sustained periods of depression in the West of England in the eighteenth and early nineteenth centuries heightened clothiers' concern about embezzlement. As noted above, the years from 1766 to the mid-1770s witnessed generally depressed trade. The food riots of $1766^{29}$ revealed considerable, though contained, tensions in the industry and for many years after work was in short supply. Gloucestershire was particularly affected and when workers there tried to find jobs in Wiltshire they encountered much hostility. ${ }^{30}$ It was this background of depressed trade and falling profitability which prompted the 1774 petition to Parliament. The mid-1780s likewise saw a coincidence of poor trade and sharpening conflict over embezzlement, while the years 1801$1802,1816-1817$ and $1826-1827$ likewise witnessed depression and attempts to clamp down upon embezzlers. However, sustained pressure on embezzlement also coincided with years of relatively prosperous trade in the West of England such as 1812-1813, 1822-1823 and 1828-1829. The two latter periods witnessed trade-union militancy among the weavers while the first coincided with fears of Luddism spreading to the West of England. There

28 B.P.P., 1840 , Vol. 23 , p. 466.

${ }^{29}$ A. J. Randall, "The Gloucestershire food riots of 1766", Midland History, X (1985), pp. 72-93.

${ }^{30}$ Bath Chronicle, 2 March 1769; Gloucester Journal, 27 February, 6 March and 13 March 1769. 
was thus no mechanistic correlation of concern with embezzlement levels and economic performance. Much depended upon the particular context and circumstances of the time. Nor should we assume a direct correlation between cases brought before the courts for embezzlement and the incidence of the crime itself. The level of prosecution, like the clothiers' attempts to check embezzlement practices, fluctuated according to the energies of vested interests involved. It also reflected the quality of intelligence available. Concern might remain general but one lucky break might reveal a network of embezzlement which could lead to many prosecutions. ${ }^{31}$ We should beware of reading too much into the ebbs and flows of prosecutions.

How much was embezzlement worth to the embezzler in the West of England woollen industry? Styles, as noted, takes the evidence of Pettat to the 1774 Committee at face value, and, reckoning on a return to the embezzler of half the wool's value, estimates that spinners and weavers might both augment their income by $20 \%$ at the very least. This would have constituted, he suggests, "a regular addition to income, the size of which was, within limits, subject to their direct control, unlike work-loads, money wage rates or the prices of consumables". ${ }^{32}$ As I have suggested, the levels of embezzlement asserted by Pettat are simply not credible. Nor, contrary to Styles' inference, was the amount of wool which could successfully be purloined elastic. Only by restraining their exactions within careful and narrow limits might embezzling woollen workers hope to remain undetected, unless of course they worked for particularly lazy or inexperienced clothiers. Further, it is necessary to remember that the supplement to income provided by embezzlement was only available when work itself was available and its contribution to the family economy was proportional to work completed. The worker who stood to gain most was the highly productive and circumspect embezzler who had a fast turnover of production, not the idle and dissolute labourer, the archetype embezzler of the clothiers' propaganda. If we take Jones' evidence of 1803 of a net loss of some 10s. per cloth and Niblett's assertion that an experienced foreman could tell the weight of a woven cloth to within a pound, we arrive at a breakdown of perhaps at most a little over 1lb of wool for the weaver and $1.5 \mathrm{lbs}$ of wool to be divided among the picker and the now factory-based scribbler and spinner. This was all from a total of around 60lbs. Even had they received the proper value of the wool they embezzled however, this

${ }^{31}$ As for example when the chance arrest of a Nymphsfield weaver, Thomas Rudder, led to the capture of an organised gang of wool thieves. Gloucester Journal, 22 November 1773.

${ }^{32}$ Styles, "Embezzlement", pp. 181, 207. 
would not have constituted anything like $20 \%$ over and above net earnings. ${ }^{33}$

The embezzler in the West of England did not, however, enjoy the full value of the fruits of his or her crime. The structure of production, entirely controlled as it was by the clothiers, meant that even the most assiduous embezzler could rarely utilise these ill-gotten gains directly. Specialists in one branch of the manufacture, few workers had a good grasp of other aspects of cloth making. And if they could not easily make whole cloths for themselves, neither could they find legitimate outlets for their unfinished products. There was no open market for small quantities of spun yarn since eighteenth-century West Country domestic spinners did not purchase raw wool and then spin as private producers but were only employed on piece work for clothiers or, increasingly rarely, for master spinners. Likewise, weavers who accumulated sufficient embezzled weft for a cloth would find great difficulty in obtaining the warp thread and would then face the problem that no market existed for simple unfulled woven cloths. In both cases, such attempts at private enterprise on the part of journeymen and women would immediately evoke grave suspicions and lead to blacklisting at the least. ${ }^{34}$ Embezzlers in the West of England, therefore, had to rely on a

${ }^{33}$ It is notoriously difficult to compute the earnings of out-workers in the eighteenth and early nineteenth centuries. The most authoritative source for the West of England woollen industry is Mann, Cloth Industry, in particular Appendix IV, pp. 322-327.

Weavers: Employers and weavers giving evidence in 1803 advanced a variety of figures for average weekly earnings but broadloom weavers probably rarely exceeded an average of 10 s per week net of deductions. As a piece of broadcloth frequently took three weeks to produce, the value of any yarn which might be embezzled from the materials must be divided by three to assess its relative contribution to weekly income. If the weaver could embezzle 1lb of Spanish wool per cloth, this might be worth 5s but the slinger would pay at the most $2 \mathrm{~s} 6 \mathrm{~d}$ for it. This would thus be worth around $10 \mathrm{~d}$ per week or $8.3 \%$ over and above clear net earnings from the loom.

Spinners: Spinning by hand was a slow process and spinners worked at very variable rates of production. In addition, rates paid for yarn varied considerably, depending both upon the quality of the fibre and upon the quality of the work done. At a rate of production of $2.5 \mathrm{lb}$ per week, a maximum rarely achieved, a spinner would have taken some 24 weeks to complete the 60lb of yarn necessary for a broadcloth. Few worked so quickly. Even if we take Pettat's exaggerated figures of a loss of $1 \mathrm{lb}$ in 12, the spinner might only embezzle 5lb of wool, worth in $\mathbf{1 7 7 4}$ around $3 \mathrm{~s} \mathrm{per} \mathbf{l b}$ or at most $1 \mathrm{~s} 6 \mathrm{~d}$ from a slinger. This would generate only the equivalent of $3.75 \mathrm{~d}$ per week. Rates for spinning Spanish wool fluctuated from as little as $4 \mathrm{~d}$ per $\mathrm{lb}$ to over $1 \mathrm{~s}$. At $8 \mathrm{~d}$ per $\mathrm{lb}$, the spinner completing the work in 24 weeks would earn $20 \mathrm{~d}$ per week. Thus the value of embezzlement, even on Pettat's figures, would have been only $19 \%$ over and above clear earnings. It seems unlikely that the domestic spinner could purloin even half that amount and avoid detection.

Family economy: Adding together the values of wool purloined from a loom and a spinning wheel (at half that claimed by Pettat) would produce an income a little below $1 \mathrm{~s}$ per week on a notional earning of $11 \mathrm{~s} 8 \mathrm{~d}$ or an $8.5 \%$ supplement.

${ }^{34}$ In fact the only labouring group which could easily utilise embezzled wool for their 
network of dealers and clothiers who organised a black market in embezzled wool, known as the slinge trade. In this clandestine and illicit market the vendor rarely received anything like the value of the goods he purloined. "I have known instances where slinge worth $6 s$. a pound has been sold for 10d." 35 Solomon Legg, a North Nibley slinge clothier, was said to have persuaded scribblers to steal wool and sell it to him "for a trifle" in 1768. ${ }^{36}$ Others did better. A letter from Chalford in 1796 lamented, "It is really shocking to reflect that there are men so depraved as to be capable of encouraging servants to embezzle their master's property and afterward receiving such property at less than half its value." ${ }^{37}$ As Miles perceptively noted, "the price of the stolen material varies according to the necessities of the slinger". 38

"It is almost impossible to trace the various means through which slinge comes into bulk", wrote Miles, but come into bulk it certainly did in the hands of the dealers and black market clothiers. "These receivers live in remote districts, carrying on some ostensible calling, and are well-known to the weavers." Usually the embezzler took the wool to the dealer. Miles in 1838 believed most slinge was moved by day, principally by women and children "as the officer has no power to stop and search them till after sunset; thus we trace the pernicious effects of slingeing upon the rising generation as well as the defect in the present law" ${ }^{39}$ Fisher, the Stroud historian, writing of his youth in the early nineteenth century, however, recalled stealthy figures crossing Minchinhampton Common in the twilight as, in all parts of the Stroud area, slinge passed from cottage to cottage..$^{40}$ Some slingers left doors open all night to receive wool and yarn. At the trial of George Poole and Richard Jones for stealing and Thomas Davis for receiving wool, the property of Messrs. Sheppards, in April 1800, "it appeared from the evidence that Davis, who carried on a considerable trade as a clothier, kept the back door of his house open at all hours of the night to receive stolen wool". John Taylor, a Melksham cloth-worker acquitted of receiving stolen wool in 1828 , was said to have told the thieves, "after you have got it [. . .] throw it over the backside of my premises". ${ }^{41}$ Pubs and, after 1830, beershops also were suspected of being "the rendezvous of slingers". ${ }^{42}$ A Wotton publican, George Edwards, was sentenced to six

own production were the rug weavers. Handloom weavers probably could likewise have used thrums to make loop pile rugs.

${ }^{35}$ B.P.P., 1840, Vol. 24 , p. 473.

${ }^{36}$ Gloucester Journal, 10 October 1768.

${ }^{37}$ Gloucester Journal, 20 June 1796.

38 B.P.P., 1840, Vol. 24, p. 473.

39 B.P.P., 1840, Vol. 24, p. 473.

${ }^{40} \mathrm{P}$. H. Fisher, Notes and Recollections of Stroud, Glos. (Stroud, 1871), p. 182.

${ }^{41}$ Bath Chronicle, 10 April 1800, and Wiltshire Record Office, A2/4/368; A2/8/Depositions, Marlborough Sessions, 1828. 
months' imprisonment in 1783 for buying stolen yarn while John Pobjoy, a Trowbridge spinner sentenced to fourteen days' imprisonment in 1818, was said to have offered stolen wool for sale to a slinger in the Wool Pack Inn. ${ }^{43}$ Some dealers collected slinge themselves from the out-workers' houses. The Minchinhampton police had a case pending in 1838 against one woman and her daughter from Pinfarthings, a hamlet on the edge of Minchinhampton Common, who, they claimed, had carried on her illegal trade for twenty five years. "She and her daughter carry a bar and collect at the weavers' houses." Hester Read had been similarly convicted of collecting wool and yarn in $1781 .{ }^{44}$ Slingers were but rarely captured when out collecting embezzled wool. A man crossing a field near Uley threw down a bag containing some 66lbs of assorted wool when challenged in 1819 and made good his escape, while four bags of wool were found in a field on Minchinhampton Common in 1822, abandoned to avoid an encounter with the forces of authority. ${ }^{45}$

The clothier who found wool or yarn secreted in the home of one of his spinners or weavers stood a reasonable chance of securing conviction. Prosecution of the slingers, however, was more difficult since proof of ownership could not always easily be established. This had been a principal complaint of the clothiers to the 1774 committee. Cooper told them "that he had in searching of suspected persons' houses, found a large quantity of wool and yarn of various sorts, different colours, different wools, and in many small quantities, and not being able to swear to the identity of any of it, the persons could not be prosecuted". Tippets likewise complained,

That although upon search large quantities of ends and yarn have been found in possession of divers persons; yet for want of being able to prove the identity of the goods, the persons in whose custody they were found could not be punished, the laws at present not compelling the persons in whose possession they are found to discover how they came by them.

42 B.P.P., 1840, Vol. 24, p. 473.

${ }^{43}$ Gloucester Journal, 28 April 1783; Wiltshire Assize and Sessions Calendars, Summer Assize, July 1818; Simpsons Salisbury Gazette, 23 July 1818.

${ }_{44}$ B.P.P., 1840, Vol. 24, pp. 473-474; Gloucester Journal, 8 October 1781. Female domestic spinners were frequently accused of embezzlement before machinery displaced them in the $1790 \mathrm{~s}$. But women continued to be charged with embezzlement into the nineteenth century. Thus of the fifty successful prosecutions for embezzlement reported by the Gloucester Journal between 1800 and 1830 , sixteen were of women. Many women took up the loom but they also were found guilty of purloining wool from factories and workshops. Most were convicted of stealing small quantities but four were convicted as receivers. For Wiltshire, where coverage is less good, women constituted six out of twenty-five successful prosecutions.

${ }^{45}$ Gloucestershire Record Office, GCL JF 11.27 (65); Gloucester Journal, 1 July 1822. 
This was why they demanded new legislation which would shift the burden of proof onto the possessor to prove his legal title to the wool rather than requiring the defrauded owner to prove the wool to be his own as was then the case..$^{46}$ The Act of 1774 did this and increased the penalty for a first offence to a fine of $£ 20$ or a month in prison. However, the receivers of slinge managed to evade this clause.

It is usual for them to purchase a small lot of wool, merely for the purpose of having an invoice to produce in case their premises should be searched. In cases where slingers have been convicted, the law directs that the condemned wool, consisting of every sort and quality, as well as waste, should be sold; and these slingers always endeavour to purchase slinge at any cost; their object is to possess themselves of a bill of sale, so that, in case of detection at any future time, they can always account for the possession of slinge. ${ }^{47}$

Occasionally it was possible for the victim of embezzlement to provide watertight evidence of fraud. Thus the wool bought from John Pobjoy by Thomas Blackburn, a small Bradford on Avon clothier, was readily recognised by its owner, John Cooper, as wool stolen from his slubbing shop because it was a peculiar German wool, finer than was common, and used by no other clothier in Trowbridge. ${ }^{48}$ Such clear-cut circumstances, however, were rare and many slingers were convicted for "having materials suspected of being embezzled" (my italics). This often led to appeals, as with Sayer v Maclean at the Gloucester quarter sessions in 1829. Maclean, who had brought the original charge, was a prominent clothier and produced other eminent manufacturers to testify to Sayer's "suspicious character". Sayer's witnesses showed that he was a clothier and therefore might legitimately have had in his possession the materials for which he was convicted. "The witnesses, however, admitted on cross-examination that they had worked for slingers and one had the effrontery to admit that he purchased from any that would offer him cloth for sale." The Chairman, in confirming sentence, said the offence struck at the roots of the industry and awarded Maclean $£ 40$ costs, although the question of proof had not been settled. ${ }^{49}$

The courts took a dim view of slingers but sentences varied. There was a lull in prosecutions following the 1774 Act but the 1780s saw a renewed attempt to eradicate embezzlement by passing swingeing sentences upon receivers. In 1781 Hester Read was sentenced to twelve months imprison-

47 B.P.P., 1840, Vol. 24 , p. 473.

48 Simpsons Salisbury Gazette, 23 July 1818.

49 Gloucester Journal, 17 January 1829. 
ment for collecting slinge from weavers. The following year a clothier, William Perrett, long suspected of buying slinge, was convicted and imprisoned for six months. George Edwards was likewise punished in $1783 .{ }^{50}$ Thereafter the courts became more severe. The Gloucester Journal reported in 1785, "The great losses sustained by the clothing trade from thefts committed by the workmen have determined the justices to carry the laws into force with the utmost vigour against those convicted", sentiments it again expressed in $1786 .{ }^{51} \mathrm{John}$ Sparrow was sentenced to seven years' transportation for possessing stolen yarn in October 1783, while John Legg was sentenced to fourteen years for receiving embezzled wool in 1786. Two years later Isaac Legg, like John, of North Nibley was given seven years' transportation on his second conviction within that time. Mark Terrett, another North Nibley clothier, received a two-year sentence for his first offence while several others got six months. The Journal noted, "From the spirit which has appeared in these prosecutions it may be hoped that those who are ruining the trade of this country by encouraging workmen to plunder their employers will not be able any longer to follow their pernicious practices with impunity." 52 Whether these hard sentences had the desired effect is not clear. For a few years after 1788 there were no more cases reported in the press but in 1796 slingeing was said to be in full swing around Chalford when nine men were convicted. The most severe sentences then, though, were fines of $£ 40$ and three months' imprisonment. And when Mark Terrett, the Nibley clothier, was, with ten others, convicted again for receiving stolen yarn in 1801 , his punishment was only a $£ 40$ fine..$^{53}$

Miles was critical of the punishments stipulated in the Act of $17 \mathrm{Geo} . I I I \mathrm{c}$. 56. "The penalty is $£ 20$ for the first offence or one months' imprisonment. A slinger prefers selling his liberty for one month to paying $£ 20$, so he is locked up; the term of imprisonment is not in proportion to the fine." 54 Workers who embezzled small quantities would have had little alternative to imprisonment because for them $\mathfrak{f} 20$ could be as much as two thirds of their annual net income. Most slinge clothiers, however, preferred to pay the fine. Thus, of those convicted in the Chalford prosecutions in 1796, William Tyler, Jacob Bath, William Niblett, George Davis and Daniel Gardiner, all clothiers, "instantly paid" fines of between $£ 30$ and $£ 40$ while John Gardiner, a weaver, had to serve three months for embezzlement as did Isaac Taylor,

${ }^{50}$ Gloucester Journal, 8 October $1781 ; 29$ July 1782; 13 October 1783.

${ }^{51}$ Gloucester Journal, 10 October 1785.

${ }_{52}$ Gloucester Journal, 13 October 1783; 3 April, 29 May and 17 July 1786.

${ }_{53}$ Gloucester Journal, 7 April 1788; 20 June and 25 July 1796; 26 October 1801.

${ }^{54}$ B.P.P., 1840 , Vol. 24, p. $475.17 \mathrm{Geo} \mathrm{III}$, c. 56 amended and consolidated earlier legislation against "Frauds and Abuses by Persons employed in the Manufacture of Hats, and in the Woollen, Linen [. . . ] Manufactures", toughening sanctions and extending rights to stop and search. 
another weaver, in a subsequent conviction. Of those convicted at Dursley in 1801 , two women, each accused of stealing one pound of yarn, were sentenced to three and four months' imprisonment and James Summers, a shoemaker, to six months for receiving. Two clothiers, convicted of receiving, both paid fines of $£ 30$ and $£ 40 .{ }^{55}$ William Cockell and William Andrews, both Westbury weavers, served two months and one month for possessing materials for which they could not give satisfactory account. ${ }^{56}$ Occasionally, a weaver might pay the fine. A quantity of embezzled yarn and wool was found upon search at the houses of Joshua Wilkins, William Evans and Joseph Hyde, all Horsley weavers, in 1816. Evans and Hyde promptly paid $£ 20$ fines while Wilkins decamped..$^{57}$ But weavers with that sort of capital were rare. Slinge clothiers would sometimes pay huge fines rather than face imprisonment. The notorious William Niblett, who was first convicted in 1796 , paid a fine of $£ 100$ in 1818 , while Fisher notes that Niblett once paid $£ 120$ for one penalty, "so great were his transactions". For some, then, the slinge-clothier's trade was very lucrative. Fisher stated that the Stroud dispensary benefitted to the tune of $£ 520$ between 1801 and 1833 , the proceeds of fines for slingeing. ${ }^{58}$ Miles wrote, "To such an extent has slingeing been carried on that there are many persons in various parts of the district who have been small clothiers, now retired from business, and who, it is notorious, made their means by slingeing." 59

Prosecutions, therefore, had only a limited effect in checking the slinge trade. Miles blamed the local authorities for its thriving condition. "The non-detection of such an organised system of pilfering must be attributed to the inefficiency and the inertness of the parish constables, who are all of them aware of the notoriety of the fact but take no means to prevent it." He also castigated the clothiers for their laziness. "The manufacturers look upon it as a certain deduction from profit, though uncertain as to amount, and there the matter ends. If the manufacturers would subscribe and employ police men throughout the country, or active constables possessed of local knowledge, most of the receivers would in a short time be outrooted." Around 1836 such a subscription was raised to appoint two officers to cover Minchinhampton, Horsley, Avening, Woodchester and Rodborough, two for Stroud and one each for Ebley and Stonehouse. The Minchinhampton officers were ex-Metropolitan police but initially they had some difficulty understanding the trade. A sergeant reported "At the first commencement the officers were not aware of the system of slingeing, but having become acquainted, have found several cases." They had, however,

58 Gloucester Journal, 26 January 1818; Fisher, Notes and Recollections, pp. 181-182.

${ }^{59}$ B.P.P., 1840 , Vol. 24 , p. 473. 
only obtained seven convictions. Miles attributed their lack of success to the apathy of the clothiers. Charles Cogswell, the Wotton constable, had traced out the slinge trade "but does not continue his exertions owing, as he says, to the apathy of the manufacturers who do not reward him for his trouble to protect their property". Cogswell considered that, "as the manufacturers take no pains to prevent slingeing, they have no right to complain". ${ }^{60}$

What was the effect of the slinge trade upon the legitimate cloth making economy? Opinions differed. A letter from Chalford published in the Gloucester Journal in 1796 claimed, "From this iniquitous practise, if not prevented, the worst of consequences may ensue, as it tends to bring the staple manufacture of the country into disrepute by secretly injuring the quality, and as it enables [the slinge clothiers] to undersell and thereby hurt the honest manufacturer." ${ }^{\prime 61}$ One Wiltshire manufacturer stated in 1838 that cloth was injured by embezzlement "and the profit consequently lessened" but another disagreed, claiming "there is embezzlement but not to any extent to injure the trade by the competition of the sellers of such goods in the market". ${ }^{2}$ This may well have been true of the quality cloths but in the coarse cloth range, especially flannel, in which there was a far higher proportion of small producers, its impact was probably much greater, such that the use of a percentage of slinge per cloth might have made the difference between profitability and bankruptcy. In Lancashire, for example, Samuel Bamford refused an offer to set up as a cotton manufacturer, claiming that he would have had to use a proportion of embezzled goods to compete with established manufacturers. ${ }^{63}$ Cogswell told Miles,

To such an extent is the slinge trade carried, that cloth can be purchased cheaper in Bristol than the cost of production at a manufacturing establishment. The Bristol market is, in consequence, the worst market, for there the manufacturer has to compete with his own stolen material. Bristol is conveniently situated for the slinge dealers of Wilts., Somerset, and Gloucestershire. ${ }^{64}$

Bristol was also the destination for much of the cloth stolen in the woollen districts and for some of the stolen wool. ${ }^{65}$ Indeed, the slinge clothier also

${ }^{60}$ B.P.P., 1840, Vol. 24, pp. $473,474$.

${ }^{61}$ Gloucester Journal, 20 June 1796.

${ }^{62}$ B.P.P., 1840, Vol. 23, p. 466.

${ }^{63}$ S. Bamford, Homely Rhymes, Poems and Reminiscences (London, 1864), p. 7.

${ }^{64}$ B.P.P., 1840, Vol. 24, p. 474.

${ }^{65}$ Cloth thefts and major thefts of wool were more intermittent but involved very costly losses. The Gloucester Journal carried reports of over 200 cloth thefts in the years from 1760-1830. In Wiltshire, where newspaper coverage is less reliable, there were reports of 66 robberies of cloth between 1811 and 1835. Many cloths were stolen from the tenter grounds where fulled cloths were stretched prior to finishing or after dyeing. The tenter 
benefitted, no doubt, from the activities of the gangs of wool thieves who periodically broke into wool lofts or stores or who robbed weavers on their way home with a new "chain". Their loot was rapidly dispatched, probably using the same routes which slinge followed. Charles Pearce, who pleaded guilty to stealing 50lb of wool from James Counsell's wool loft in Kingswood in 1829 , was told by his "fence" that the wool would be two or three miles out of Wotton within a day of its theft. ${ }^{66}$ The black economy of slinge thus overlapped with the underworld economy of crime. Some clothiers undoubtedly prospered within it. A clothier named Evans was discovered to have between $£ 300$ and $£ 400$ worth of embezzled wool on his premises shortly before $1838 .{ }^{67}$ Such men might undercut the honest clothier in price or they might compete on price in the knowledge that their profit margins were much greater. Their competition must have adversely affected the economy of the legitimate clothier, though this probably was felt most keenly in Gloucestershire where more clothiers produced mixed or lowerquality cloths which were more likely to feel the pinch than the superfine trade in which Wiltshire clothiers increasingly concentrated.

How far does the history of embezzlement in the West of England woollen trade in the years between 1780 and 1840 support the arguments advanced by Linebaugh and Rule that this period saw concerted attempts to eradicate these "pernicious practices" and to redefine industrial relations to the advantage of capital? The answer has to be ambiguous. Certainly the Act of 1774 redefined and re-stated the law on embezzlement and considerably stiffened the penalties. However, the West of England woollen workers lost no rights thereby since their "peculiar perquisites" always existed by custom and not by law. Unlike the weavers of Essex, they were never offered any financial compensation to relinquish perks like thrums. ${ }^{68}$ Indeed, the case of thrums is instructive since, while many clothiers continued to accept their weavers' retention of them, on occasion prosecutions were brought for embezzling thrums. Again, there was certainly a continuing struggle on the clothiers' part to eradicate embezzlement through private and associated prosecutions and by closer subordination of their workforce. However, such attempts can be seen before 1760 and were to

grounds presented a pretty sight to travellers but they were also an easy target for thieves. Few clothiers in the West of England chose, as did Benjamin Gott at Bean Ing, to enclose their extensive tenter grounds behind high walls for security (see R. Warner, Excursions from Bath (Bath, 1801), p. 322, and Crump, Leeds Woollen Industry, p. 263). Much stolen cloth was sold at Bristol, but, cut up into smaller pieces, they were also sold much nearer to where they had been stolen. Large-scale thefts of wool were harder to trace but again Bristol provided a significant bulk outlet, the wool thence being "recycled"around the woollen-making districts.

${ }^{66}$ Wilts. R.O., A2/8/Devizes Sessions, January 1829.

${ }^{67}$ B.P.P., 1840, Vol. 24, p. 474.

${ }^{68}$ Rule, The Experience of Labour, pp. 126-127. 
continue after 1840 , while at best these efforts were intermittent and rarely particularly effective. Indeed, neither the sharpening of legislative sanctions nor the clothiers' attempts to enforce them had much discernible effect upon the crime itself. The slinge trade in the 1830s in fact appears better organised than ever, though this may merely reflect superior historical information. The period under review certainly saw major changes in the structure and industrial relations of the industry but these were consequent upon the introduction of new technologies in the preparatory branches of the trade with the rise of the factory system, not upon attempts to eradicate embezzlement.

Clothiers in the late eighteenth century had in many cases seen the factory as a principal means of combatting embezzlement. Indeed, this was always a major reason advanced to justify the introduction of loomshops from the 1720 s onwards. ${ }^{69}$ This hope, however, proved false, since the factories seem to have been equally plagued. The processes in the factory all produced waste, known as flight or flock. This was generally collected up and sold by the manufacturer to a "flocker", a manufacturer of paddings, blankets and the like. These men increasingly came from Yorkshire as the industry there expanded. Miles outlined the processes producing waste: "1. Hard ends from the sorter. 2. Waste from the spinner. 3. Waste from the weaver. 4. Millpuff from the gigmill. 5. Shearflock from the cutters. 6. Flight from the scribblers and carders, the mixture of all the above, and the sweeping of the factory." Any of this waste could easily be pocketted by the factory worker and sold either to a slinger or to a flocker, of whom Miles had a low opinion.

The general character of the flocker is that he will purchase wool from any person under any circumstances, as indiscriminately as a marine store dealer. These flockers generally court the company of those servants engaged in the factories who, by reason of their situation, are enabled to throw in some good wool to the flight and waste which the flocker may have purchased from the manufacturer.

Miles noted that the flockers were often suspected of receiving slinge, the denomination of "flight" from their legitimate trade serving as a cover for the transfer of embezzled wool. ${ }^{70}$

The factory workforce also had access to good yarn and wool which was fairly easily stolen, though, again, few were caught. The amounts of wool found on the persons of purloining factory workers were usually very small but over a period of time would have constituted no small loss to the unwary clothier. Thus Ann Brickler was convicted and sentenced to one month's

${ }^{69}$ B.P.P., 1802/3, Vol. 5, pp. 14, 15; B.P.P., 1802/3, Vol. 7, p. 264.

${ }^{70}$ B.P.P., 1840, Vol. 24, pp. 474, 475. 
imprisonment for stealing a small quantity of yarn from Bush, Newton and Bush of Bradford on Avon in 1816; Samuel Antill stole half a pound of yarn from Thomas Vaisey of Kingswood in 1818; George Hillman stole two ounces of yarn from J. Smith's workshops in Uley in 1823; John Comely stole three quarters of a pound of abb from Long's mill at Charfield in 1828; and Isaac Hook Partridge stole four ounces of yarn from John Millman's Kingswood mill in 1829. They were all captured with the wool in their possession leaving the mill. In the case of Partridge, Millman had several times noticed he was losing abb from his workshops and suspected Partridge. Early one morning Millman was told that some yarn was missing from the weaving shop and that Partridge had been seen to go up to Isaac Hanks' loom and cut off abb from the bobbins. Partridge was stopped as he was leaving the mill for his breakfast and the yarn was found inside his hat. ${ }^{71}$ Whether or not the losses from the factories matched those from outworkers is impossible to tell. Miles suspected they were large. "In some cases I have observed small cake and apple shops to be open near the factories, and I much doubt whether they may not be inducements for children to barter at them whatever yarn they can continue to thieve." 72 It is possible to speculate that the attitudes of the old out-working industry - and of course weaving remained principally an out-working trade until the 1840 s - were imported into the factory system. It is more likely, however, that pilfering took place in factories because opportunities for theft presented themselves and because a black market already existed for embezzled materials. It is certainly notable that, for all their claims about the need for shop and factory work to eradicate theft, clothiers' security regimes in their factories were so poor.

What was the influence of embezzlement upon economic and social relations? For the clothiers the economic losses resulting from embezzlement undoubtedly had an influence on their attitude towards their workforce. Not all were as choleric as Temple who frequently accused the woollen workers of being guilty of "frauds, embezzlement, bad workmanship and waste of materials"73 but the frequency with which the clothiers raised the spectre of embezzlement is indicative that it remained an enduring source of irritation for them. However, mixed up with complaints about embezzlement were also criticisms of the woollen workers' laziness, while demands for means of tighter discipline to curb theft also were aimed

${ }^{71}$ Wilts. R.O., A2/4/362; Wiltshire Assizes and Sessions Calendars, Devizes Sessions, January 1818; Gloucester Journal, 9 June 1823; 15 March 1828; Wilts. R.O., A2/4/373; A2/8/Marlborough Sessions, October 1829.

72 B.P.P., 1840, Vol. 24, p. 473.

${ }^{73} \mathrm{~W}$. Temple, The Case as it now Stands between the Clothiers, Weavers and other Manufacturers with regard to the late Riot in the County of Wilts. (1739), p. 32. See also Temple, $A$ Vindication of Commerce and the Arts (1758). 
to help eradicate other customary practices such as St. Monday or the extended meal breaks enjoyed by shop-based scribblers and shearmen. ${ }^{74}$ Indeed, among the evidence on embezzlement given to the 1774 Parliamentary Committee were complaints, as that of William Peach, about workers who simply would not finish their pieces. ${ }^{75}$ While the old Elizabethan apprenticeship statutes forbade a journeyman from leaving his work unfinished and while wilful damage to the clothier's property could be prosecuted under a variety of acts, the out-working journeyman could not be forced to work if he chose not to, nor could the clothier legally enter the worker's house and repossess his materials, provided the journeyman claimed to be still working on them. Attempts to repossess clothiers' property during the Frome weavers' strike in 1822 provoked an angry rebuke from the Home Office while a similar case, supposedly for embezzlement, was dismissed by the judge at the Wiltshire Lent Assizes in $1826 .{ }^{76}$ For the clothiers this was the negative side of the putting out system. While it spread the capital costs and risks of the trade widely, it meant that, when food was cheap and distractions from the loom and shearshop numerous, it proved sometimes impossible to fill urgent orders for cloth. Such frustrations could easily exacerbate anger over losses from embezzlement. This is not to argue that these losses were negligible. However, it is noticeable that charges of embezzlement and frauds frequently coincided with periods of poor industrial relations and with disputes. There has to be at least a strong suspicion that the clothiers used embezzlement as a useful propaganda weapon with which to try to undermine any sympathy for their workers' cases which local magistrates and rate payers might entertain in times of dispute. ${ }^{77}$ This might help explain why, for all these charges, disinterested commentators continued to be amazed at the lackadaisical attitude of many clothiers to their own quality control measures. Clothiers were far more

${ }^{74}$ For example, shearmen notionally worked from 6 a.m. to 6 p.m. but custom allowed at least five meal breaks. See A. J. Randall, "The Shearmen and the Wiltshire Outrages of 1802: Trade Unionism and Industrial Violence", Social History, 7 (1982), pp. 283-304. ${ }^{75}$ Commons Journal, Vol. 34, p. 452.

${ }^{76}$ H.O. 41/7, Hobhouse to Sainsbury, 6 July 1823; Wiltshire Assize and Sessions Calendars, Lent Assizes, March 1826; Devizes Gazette, 9 March 1826.

$n$ As, for example, Temple's tirade against the lax morality of the woollen workers in 1738 in the dispute between the Wiltshire clothiers and their weavers over wages (Temple, The Case as it now Stands, pp. 7, 32); see also the pamphlet defending the clothiers published during the long dispute between the clothiers and weavers of Gloucestershire over the issue of wage rating in the years around 1756 (A State of the Case and a Narrative of the Facts relating to the late Commotions and Risings of the Weavers (1757), pp. iv, 2-4); see also the way in which both the West of England clothiers and their counsel continued to raise the issue of embezzlement before the Select Committee investigating their petition to repeal the old regulatory legislation in 1803 even though there was no dispute about the continued enforcement of anti-embezzlement legislation (B.P.P., 1802/3, Vol. 5, pp. 16-17). 
concerned by the more expensive, though less frequent, losses of finished cloths from their tenter grounds and by the theft of wool from their lofts than they were by embezzlement, which according to Miles they saw "as a certain deduction from profit". ${ }^{78}$ Did the clothiers, like the woollen workers, in fact view a modest level of embezzlement simply as one of the costs of the trade, whatever their public posture might be? Perhaps it was only when levels exceeded their notions of acceptable losses that they took action? Perhaps, intriguingly, like their workers they too were prisoners of customary expectations and rather less the dynamic economic rationalisers the textbooks would presume? This would certainly accord to the undoubted entrepreneurial failure of many clothiers in the West of England to adapt to the increasingly harsh economic climate after $1815 .^{79}$

How, for their part, did the woollen workers view embezzlement? I have argued elsewhere that in conflicts with capital in the eighteenth century these workers' attitudes were informed by a moral economy which rested upon mutually agreed areas of control, licence and autonomy ${ }^{80}$ How far was the immoral economy of embezzlement compatible with this? Was embezzlement indeed seen as immoral or as what Rule has termed a "social crime", ${ }^{81}$ sanctioned by customary practice, as a quid pro quo for capitalist exactions? Again, we cannot be sure. Certainly, weavers' unions condemned embezzlement and threatened to dismiss and impeach any member found guilty of the crime. For example the Gloucestershire Woollen Cloth Weavers' Society, established in 1802 to petition for the retention of the old regulatory legislation, included in its Rules a clause offering rewards to anyone bringing forward evidence of embezzlement while the Wiltshire Weavers' Society likewise placed advertisements in the Bath papers offering money for the discovery of embezzlers. Clothiers tended to view such actions or protestations with cynicism. George Wyatt, the Stroud clothier, told in 1838 a story of the reaction of the congregation to a sermon criticising embezzlement preached by a Dissenting minister in the town. "Many weavers were present and on coming out of the chapel they expressed astonishment that slingeing should have been denounced, saying 'Where's the harm in taking a vew ends?' "82 Miles in 1838 believed that embezzlement was carried on mostly by "the old weavers", implying that

78 B.P.P., 1840, Vol. 24 , p. 473.

${ }^{79}$ For discussion of the failure of the West of England after 1826 see Mann, Cloth Industry, pp. 157-193.

${ }^{80}$ A. J. Randall, "The Industrial Moral Economy of the Gloucestershire Weavers in the Eighteenth Century", in J. Rule (ed.), British Trade Unionism 1750-1850: The Formative Years (London, 1988), pp. 29-51.

${ }^{81}$ J. Rule, "Social Crime in the Rural South in the Eighteenth and Early Nineteenth Centuries", Southern History, 1 (1979), pp. 135-153.

${ }^{82}$ B.P.P., 1802/3, Vol. 5, pp. 15, 16, 17; B.P.P., 1840, Vol. 24, p. 413. 
the younger weavers took a more "respectable" view of the crime. A sergeant of police, with the policeman's jaundiced eye on human nature, believed "if an opportunity occurs, the generality of weavers would not let it escape" ${ }^{83}$ Clearly many did embezzle wool. Equally, many did not. Embezzlement could provide a useful, if relatively minor, contribution to a family economy but it also involved risk. A few extra pennies a week might not seem worth the possibility of being blacklisted and finding no work was available when times grew hard. A clue to the woollen working community's attitude may be gleaned from the fact that, while I have come across no example of the crowd acting to defend the interest of the embezzling worker, I have equally discovered no occasion when such workers were impeached by their fellows. Most informants had in fact themselves been captured and turned King's Evidence. ${ }^{84}$ The community, however, held no such qualms about impeaching upon cloth thieves or the wool theft gangs. Customary attitudes to the law rarely reflected its letter. Certainly, to pursue Rule's point, the West of England woollen workers were subjected to the oppression of the clothiers, to truck, false measures and unreasonable and arbitrary deductions from earnings. It is possible to construct a value system in which embezzlement reflected "a field of force" in which the property of the "good honest gentlemen" was left unmolested while the carping, grinding, truckster clothiers' wool was purloined as some recompense by their workers. Such constructions have a moral symmetry which is appealing but it seems clear that good honest gentlemen lost wool with the rest. We need not push the contrast between moral and immoral economies too far. The moral economy reflected an open community consensus. Embezzlement was a private affair which reflected individual characters, circumstances and opportunities.

If the study of embezzlement in the West of England woollen industry in the years of the Industrial Revolution cannot be said to offer unqualified support for Rule's concept of "a field of force", neither does it offer much encouragement for Linebaugh's argument that this period witnessed a deliberate and generally successful attempt to eradicate perquisites and to redefine labour-capital relations. While the role of perquisites was an important aspect in the formulation of the nineteenth-century wage ${ }^{85}$ and while clothiers continued to complain of the cost of embezzlement, their

83 B.P.P., 1840 , Vol. 24 , p. 474.

${ }^{84}$ As, for example, the case of William Niblett, referred to above. Niblett, a notorious slinger, was convicted and sentenced to death for forgery but had his sentence commuted to transportation by giving the magistrates a long list of names of slingers and details of his illegal trade. See Fisher, Notes and Recollections, p. 182.

${ }^{85}$ For an interesting discussion of this, see L. D. Schwarz, "The Formation of the Wage: Some Problems", in P. Scholliers (ed.), Real Wages in Historical Perspective (Oxford, 1989), pp. 21-39. 
attempts to eradicate it proved at best half-hearted. The levels of embezzlement and its rewards for the embezzler were certainly not on the scale Styles suggests, though his point that tougher legislative sanctions did not necessarily translate into harsher sentencing or more effective policing is well made. ${ }^{86}$ These somewhat negative conclusions may simply reflect the particular characteristics of the West of England and other comparable regional investigations are needed to advance the debate.

The study of crime in the eighteenth and nineteenth centuries offers us a fascinating peep show into the daily lives of ordinary people and their economic and social relations. We must recognise, however, that what we see are but glimpses, and attempts to impose clear order upon them may reflect more the constraints imposed by the historian's typology and his sources than the reality of the participants. The case of James Signell, aged 20 years, and William Watkins, aged 17 years, committed and held over for the Assizes at the Devizes Sessions in January 1818, may serve as exemplar. Both were accused of breaking and entering the premises of Mary Blick at North Bradley and stealing two yards of broad cloth, valued at 20 shillings. At the Lent Assizes they were found guilty and sentenced to seven months' hard labour. Our evidence of these cloth thieves comes from the Assize and Sessions' calendars of prisoners, seemingly unimpeachable sources. ${ }^{87}$ And indeed, the information obtained is accurate but it is also highly misleading. This we know by the good fortune that a newspaper carried a detailed report of this seemingly uninteresting prosecution. "The prisoners" the paper reported, "were very interesting youths, and there was no person in the court but would have been glad to see Mary Blick and her whole family in their place." The youths had been out drinking and

agreed to adjourn to Mary Blick's to see Miss Bathania Blick alias Newberry, alias Tanner, alias Fanny, for by all those names she has been known. Fanny is the name by which she is known at her mother's and by which she is asked for. On the youths arriving at the hospitable mansion of Mary Blick, Fanny was engaged in private conversation upstairs, with Adonis in the form of the prosecutor's carter. When they had finished what they had to say, B. and her sister came to the two youths whom they entertained with love and drink for two hours. The boys went away but not fully satisfied with the charms of B. they resolved to return [...] When they returned, however, they found that their place was occupied by more fortunate lovers [. . . ] and they then resolved to have a frolic [...] They took the cloth which was hanging in the passage and threw it down in the garden belonging to this temple of the loves and graces. This was their crime [. . . ] The judge, taking the early appearance to drinking and, as he observed, to worse into his

${ }^{86}$ Styles, "Embezzlement”, pp. 193-194.

${ }^{87}$ Wiltshire Assize and Sessions Calendars, Devizes Sessions, January 1818; Lent Assizes, March 1818. 
consideration, charged the jury accordingly and they were sentenced to seven months imprisonment. ${ }^{88}$

Our cloth thieves, then, turn out not to be cloth thieves at all, the house of Mary Blick neither workshop nor retail shop but a bordello, and their sentence more a reflection of their morals than of any crime. Even today, if in a different way, the case of Signell and Watkins remains a cautionary tale. While we may indeed set out "to specify the precise character and extent of change [in embezzlement practices] in context", we must recognise that our final picture will be liable, in spite of our best endeavours, to very considerable distortions. 